\title{
Identification of side population cells in human lung adenocarcinoma A549 cell line and elucidation of the underlying roles in lung cancer
}

\author{
TONG XIE ${ }^{1 *}$, LINGZHAO MO $^{2 *}, \mathrm{LI} \mathrm{LI}^{2}$, NAIQUAN MAO ${ }^{1}$, DANRONG LI ${ }^{3}$, DESENG LIU ${ }^{1}$, \\ CHUANTIAN ZUO ${ }^{1}$, DINGMING HUANG ${ }^{1}$, QI PAN ${ }^{1}$, LI YANG $^{1}$ and SHOUFENG WANG ${ }^{1}$
}

Departments of ${ }^{1}$ Thoracic Surgery and ${ }^{2}$ Gynecologic Oncology, The Tumor Hospital Affiliated to Guangxi Medical University;
${ }^{3}$ Experimental Centre, Guangxi Medical University, Nanning, Guangxi 530021, P.R. China

Received November 7, 2015; Accepted June 29, 2017

DOI: $10.3892 / \mathrm{ol} .2018 .7956$

\begin{abstract}
The present study aimed to isolate and characterize side population (SP) cells in the human lung cancer A549 cell line, and elucidate the molecular mechanism of SP cells underlying lung cancer. The SP and non-SP (NSP) cells in A549 cells were isolated and their differentiation was analyzed by fluorescence-activated cell sorting. An in vitro plate clone assay, Matrigel ${ }^{\circledR}$ Transwell assay and chemoresistance analysis of the sorted SP and NSP cells were performed. In addition, the sorted SP and NSP cells were injected into BALB/c nude mice to detect their tumorigenic potential in vivo. The expression of ATP-binding cassette sub-family G member 2 (ABCG2) in transplanted tumors was detected by immunohistochemistry. The SP and NSP cells were successfully isolated. The results demonstrated that SP cells accounted for $1.09 \%$ of live A549 cells. SP cells produced SP and NSP cells, while NSP cells only produced NSP cells. In addition, SP cells formed more colonies, exhibited improved invasive ability and increased levels of chemoresistance compared with NSP cells in vitro. SP cells demonstrated a higher tumorigenic potential in BALB/c nude mice, and the number of ABCG2-positive cells in the SP xenograft tumors were significantly increased compared with
\end{abstract}

Correspondence to: $\mathrm{Dr} \mathrm{Li} \mathrm{Li}$, Department of Gynecologic Oncology, The Tumor Hospital Affiliated to Guangxi Medical University, 72 JiangBei Avenue, Nanning, Guangxi 530021, P.R. China

E-mail: lixiangliangwz@163.com

*Contributed equally

Abbreviations: ABCG2, ATP-binding cassette sub-family G member 2; CSCs, cancer stem cells; DMEM, Dulbecco's modified Eagle's medium; FACS, fluorescence-activated cell sorting; HPLC, high performance liquid chromatography; SP, side population; NSP, non-side population; VP-16, etoposide; NVB, vinorelbine

Key words: lung cancer, cancer stem cells, side population cells, ABCG2 that in the NSP xenograft tumors. The present study indicated that SP cells isolated from the human lung cancer A549 cell line demonstrated increased tumorigenicity, and improved invasive ability and chemoresistance compared with NSP cells. In addition, detection of ABCG2 expression may assist in predicting the chemotherapeutic outcome of patients, and serve as a target for treating lung cancer.

\section{Introduction}

Lung cancer is the leading cause of cancer-associated mortality worldwide and has a poor prognosis (1). Although there has been considerable progress in therapies, the incidence and mortality rates (number of cases or deaths per 100,000 persons per year) are increasing, with a low overall 5-year survival rate (2). Following $>10$ years of study, advances in the field of cancer and stem cell biology have highlighted the important role of the cancer stem cells (CSCs) in tumor progression (3). Accumulating evidence has indicated that CSCs are a small population of cells with the ability for self-renewal and extensive proliferation potential (4). Additionally, CSCs are thought to be responsible for resistance to chemotherapy and radiation, tumor growth, invasion and metastasis $(5,6)$. It may therefore be hypothesized that targeting the CSCs in tumors will be required to achieve an effective therapeutic strategy for cancer.

Previously, an increasing number of studies on CSCs have been performed to elucidate the mechanisms of the development and drug resistance of tumors $(7,8)$. Goodell et al (9) first identified in 1996 that side population (SP) cells in mouse bone marrow possessed hematopoietic stem cell activity using the Hoechst 33342 fluorescent dye. Ho et al (10) also demonstrated that SPs isolated from tumor tissues and cell lines of human lung cancer were enriched with stem-like cancer cells. In addition, accumulating evidence indicates that SP cells are a common phenotype of stem cells, and are considered as an ideal model for stem cell research (11). These SP cells have been suggested to possess CSC-associated properties, including self-renewal, asymmetric division into SP and non-SP cells and drug resistance (12). Additionally, numerous studies have indicated that SP cells exist in a variety of human tumors, such 
as lung (13), gastroenterological (14) and ovarian cancer (15) and bone sarcoma (16). The expression of ATP-binding cassette sub-family G member 2 (ABCG2) has been demonstrated to affect the phenotypic characteristics of SP cells, and exhibit a marked correlation with tumor recurrence and drug resistance (17), suggesting that $\mathrm{ABCG} 2$ may be a candidate for the detection of SP cells. Despite this, at present, investigating the characteristics of SP cells and illustrating their underlying mechanism in the tumor initiation and development of lung cancer remains a challenge.

In the present study, SP cells were isolated from the human lung cancer A549 cell line, and their CSC-associated biological properties were characterized in vitro and in vivo. The aim of the present study was to isolate and characterize SP cells, and to elucidate their molecular mechanisms underlying lung cancer. This may assist an improved understanding of the key roles of SP cells in lung cancer, and to explore novel targets for the treatment of this disease.

\section{Materials and methods}

Cell lines. The human lung cancer A549 cell line was purchased from Peking Union Medical College Cell Bank (Shanghai, China) and cultured in Dulbecco's modified Eagle's medium (DMEM) supplemented with $10 \%$ fetal bovine serum (FBS; Welgene Ltd., Gyeongsan, South Korea) in a humidified incubator with $5 \% \mathrm{CO}_{2}$ at $37^{\circ} \mathrm{C}$.

Fluorescence-activated cell sorting (FACS) of SP and non-SP cells. Human lung cancer A549 cells in the logarithmic growth phase were digested with trypsin (Gibco; Thermo Fisher Scientific, Inc., Waltham, MA, USA) and collected. Then, the A549 cells $\left(5 \times 10^{6}\right.$ cells $\left./ \mathrm{ml}\right)$ were resuspended at $37^{\circ} \mathrm{C}$ in DMEM containing $2 \%$ FBS and labeled with the DNA binding dye Hoechst 33342 (Sigma-Aldrich; Merck $\mathrm{KGaA}$, Darmstadt, Germany) at a concentration of $5 \mu \mathrm{g} / \mathrm{ml}$ for $60 \mathrm{~min}$ at $37^{\circ} \mathrm{C}$, either alone or with $50 \mu \mathrm{g} / \mathrm{ml}$ verapamil (Sigma-Aldrich; Merck KGaA). The incubation process was performed in the dark with gentle agitation every $15 \mathrm{~min}$. Subsequent to staining, the cells were centrifuged at 1,200 x g for $5 \mathrm{~min}$ at room temperature, resuspended in ice-cold PBS containing $2 \% \mathrm{FBS}$ and stored at $4{ }^{\circ} \mathrm{C}$ in the dark prior to FACS with flow cytometry. Cells were counterstained with $2 \mu \mathrm{g} / \mathrm{ml}$ propidium iodide (PI; Sigma-Aldrich; Merck KGaA) and cell sorting was performed using a FACS Vantage flow cytometer (BD Biosciences, San Jose, CA, USA). The sorted SP and non-SP (NSP) cells were collected separately and cultured in DMEM containing $10 \% \mathrm{FBS}$ at $37^{\circ} \mathrm{C}$ with $5 \% \mathrm{CO}_{2}$. A week later, the Hoechst 33342-marked subpopulations of SP and NSP cells were then investigated with flow cytometry as aforementioned. The sorted SP or NSP cell suspension was smeared onto slides and the fluorescence signals were detected under a fluorescence microscope.

Plate cloning assay. The sorted SP and NSP cells were seeded separately in 24-well plate with concentrations of 50, 100 and 200 cells/well. All experiments were performed in triplicate. Two weeks subsequent to cell culture, cells were stained with $0.75 \%$ Giemsa for $5 \mathrm{~min}$ at $37^{\circ} \mathrm{C}$. Then, colonies of $\geq 50$ cells were counted in 5 randomly selected fields of view under a light microscope (CX31, Olympus; magnification, $\mathrm{x} 40)$, and the rate of clone formation was calculated.

Matrigel $^{\circledR}$ Transwell assay. The invasive ability of SP and NSP cells was determined using a Transwell chamber with Matrige ${ }^{\circledR}$-coated membrane (24-well insert; pore size, $8 \mathrm{~mm}$; BD Biosciences) in vitro according to the manufacturer's protocol. SP and NSP cells were collected separately and re-suspended in DMEM containing 1\% FBS. Then, $100 \mu 1$ cells $\left(1 \times 10^{5}\right.$ cells/well) were added to each insert of the upper well of the chamber containing serum-free media, and $600 \mu \mathrm{l}$ DMEM containing 10\% FBS was added into the lower compartment of the chamber. Each group was assayed in triplicate. Following $24 \mathrm{~h}$ incubation at $37^{\circ} \mathrm{C}$, Transwell chambers were removed and cells that had invaded the membrane were fixed with $10 \%$ formaldehyde at $37^{\circ} \mathrm{C}$ for $30 \mathrm{~min}$, stained with $0.75 \%$ Giemsa for $5 \mathrm{~min}$ at $37^{\circ} \mathrm{C}$ and sealed on slides. A total of 5 high-power visual fields were examined randomly under a light microscope (magnification, $\mathrm{x} 400$ ) and the invasive cell numbers were counted.

Chemoresistance analysis. The SP and NSP cells seeded on 96-well plate $\left(1 \times 10^{4}\right.$ cells/well) were cultured at $37^{\circ} \mathrm{C}$ for $12 \mathrm{~h}$ and treated with different concentrations of 5 chemotherapeutic drugs, consisting of cisplatin (DDP; 40, 80, 120, 160 and $200 \mu \mathrm{g} / \mathrm{ml}$, 5-fluorouracil (5-FU; 50, 100, 150, 200 and $250 \mu \mathrm{g} / \mathrm{ml})$, etoposide (VP-16) $(60,90,120,150$ and $180 \mu \mathrm{g} / \mathrm{ml})$, vinorelbine (NVB; 20, 40, 60 and $80 \mu \mathrm{g} / \mathrm{ml}$ ), gemcitabine $(10,30,60,90$ and $120 \mu \mathrm{g} / \mathrm{ml}$ ). Blank (only medium without cells) and negative (cells without any drug treatment) controls were set, and each sample group was analyzed in triplicate. Cells were treated with Cell Counting Kit 8 (Biosharp, Hefei, China), according to the manufacturer's protocol, for $24 \mathrm{~h}$ after incubation at $37^{\circ} \mathrm{C}$ with the aforementioned chemotherapeutic drugs. The half-maximal inhibitory concentration $\left(\mathrm{IC}_{50}\right)$ was calculated by comparing SP with NSP cells.

In addition, the intracellular chemotherapeutic drug level was examined using high performance liquid chromatography (HPLC). According to the chemotherapeutic susceptibility assay, DDP (120 $\mu \mathrm{g} / \mathrm{ml}), 5-\mathrm{FU}(120 \mu \mathrm{g} / \mathrm{ml}), \mathrm{VP}-16(120 \mu \mathrm{g} / \mathrm{ml})$, NVB $(70 \mu \mathrm{g} / \mathrm{ml})$ and GEM $(70 \mu \mathrm{g} / \mathrm{ml})$ were added into cells. The SP and NSP cells seeded in 6-well plate $\left(1 \times 10^{5}\right.$ cells/well) were incubated at $37^{\circ} \mathrm{C}$ for $2 \mathrm{~h}$, washed with PBS 3 times and then resuspended with $500 \mu \mathrm{l}$ distilled water. The cells in the plate were disrupted by repeating freeze-thawing and checked under the microscope to ensure that there were no intact cells. The cell lysate was collected and centrifuged at $100 \mathrm{x} \mathrm{g}$ at $37^{\circ} \mathrm{C}$ for $5 \mathrm{~min}$. The supernatant was carefully removed, and HPLC was performed using Shimadzu LC-10A (Shimadzu, Kyoto, Japan) equipped with a GraceSmart RP C18 column $(250 \times 4.6 \mathrm{~mm}, 5 \mu \mathrm{m})$ at room temperature. DDP: The mobile phase composed of methanol in water $(75: 25, \mathrm{~V} / \mathrm{V})$ eluted with $1 \mathrm{ml} / \mathrm{min}$ flow rate. The injection volume was $20 \mu \mathrm{l}$ and the column temperature was room temperature. The peak time of DDP was about 8.65 min under detection wavelength of $254 \mathrm{~nm}$. 5-FU: The mobile phase composed of ethanol in $0.01 \mathrm{~mol} / \mathrm{l}$ potassium dihydrogen phosphate $(2: 98, \mathrm{~V} / \mathrm{V})$ eluted with $1 \mathrm{ml} / \mathrm{min}$ flow rate. The injection volume was $20 \mu \mathrm{l}$ and the column temperature was room temperature. The peak time of 5-FU was $\sim 5.70$ min under detection wavelength $265 \mathrm{~nm}$. VP16: 

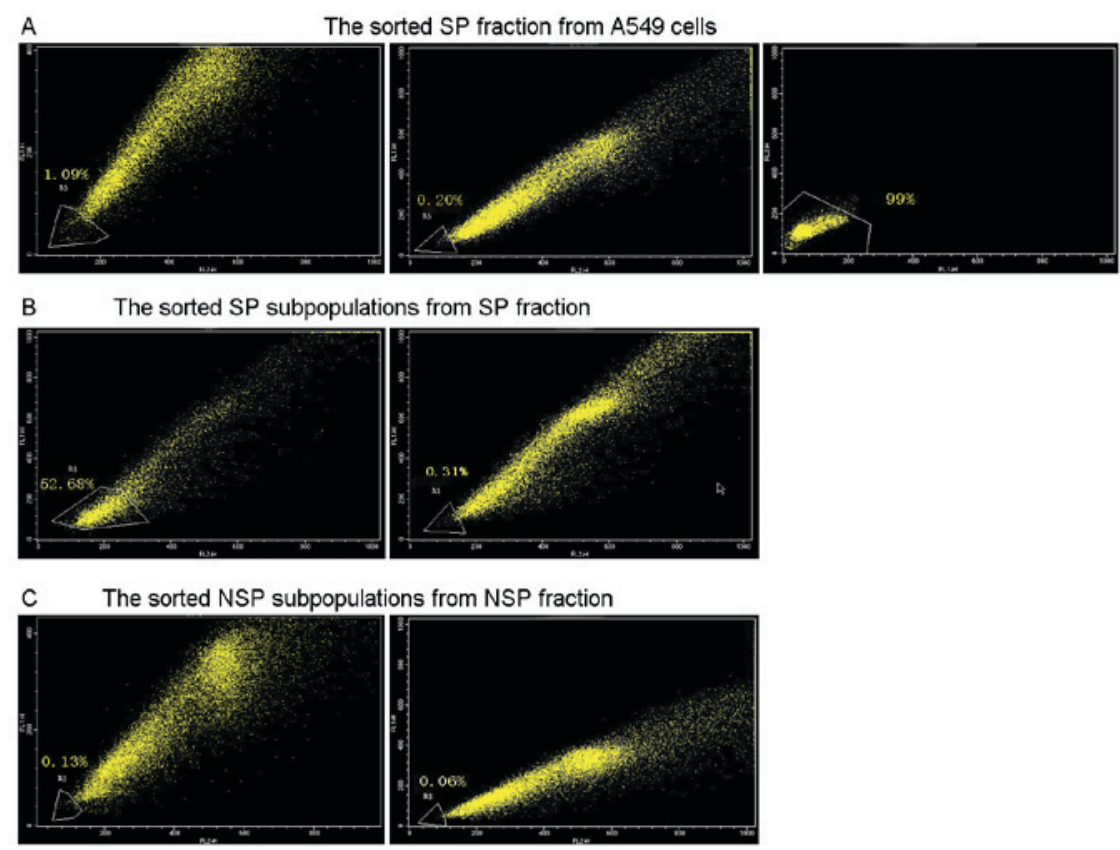

Figure 1. Fluorescence-activated cell sorting of SP and non-SP cells using flow cytometry. (A) Hoechst $33342^{\text {low/neg }}$ fraction accounted for $1.09 \%$ of live cells, which decreased to $0.2 \%$ after treatment with Verapamil, and the sorted purity of SP cells was $99 \%$. (B) Hoechst $33342^{\text {low/neg }}$ and Hoechst $33342^{\text {high }}$ cells were identified in the SP fraction, with $52.86 \%$ of living cells being Hoechst $33342^{\text {low/ng }}$. However, the percentage decreased to $0.31 \%$ following treatment with Verapamil. (C) Only Hoechst $33342^{\text {high }}$ cells were identified in the NSP fraction. Hoechst $33342^{\text {low/neg }}$ cells were isolated at a very low rate of $0.13 \%$ in living cells, which decreased further to $0.06 \%$ following treatment with Verapamil. SP, side population; NSP, non-side population.

The mobile phase composed of methanol in water $(55: 45, \mathrm{~V} / \mathrm{V})$ eluted with $1 \mathrm{ml} / \mathrm{min}$ flow rate. The injection volume was $20 \mu \mathrm{l}$ and the column temperature was room temperature. The peak time of VP16 was about 6.92 min under detection wavelength of $254 \mathrm{~nm}$. NVB: The mobile phase composed of acetonitrile in $0.01 \mathrm{~mol} / \mathrm{l}$ potassium dihydrogen phosphate $\mathrm{pH} 5.0$ (60:40, $\mathrm{V} / \mathrm{V}$ ) eluted with $1 \mathrm{ml} / \mathrm{min}$ flow rate. The injection volume was $20 \mu \mathrm{l}$ and the column temperature was room temperature. The peak time of NVB was about 6.39 min under detection wavelength of $269 \mathrm{~nm}$. GEM: The mobile phase composed of acetonitrile in $0.01 \mathrm{~mol} / 1$ potassium dihydrogen phosphate pH $5.1(7.5: 92.5, \mathrm{~V} / \mathrm{V})$ eluted with $1 \mathrm{ml} / \mathrm{min}$ flow rate. The injection volume was $20 \mu \mathrm{l}$ and the column temperature was room temperature. The peak time of GEM was about $4.90 \mathrm{~min}$ under detection wavelength of $268 \mathrm{~nm}$. Quantitative analysis of the intracellular concentrations of these drugs was then performed using an external standard method as previously described (18).

In vivo xenograft model in BALB/c nude mice. A total of 8 female and 7 male BALB/c nude mice at the age of 4 weeks, weighing 8-20 g, were obtained from Shanghai SLRC Laboratory Animal Center (Shanghai, China). All the mice were housed under a SPF condition (12-h light/dark cycle, $50 \%$ relative humidity, between 25 and $27^{\circ} \mathrm{C}$ ) with free access to food and tap water.

The sorted SP and NSP cells were respectively injected into the upper flanks of 17 nude mice at a concentration of $10^{3}-10^{7}$ cells per injection, totaling 34 injection sites. Among these nude mice, one was injected with $1 \times 10^{3} \mathrm{SP}$ cells in each flank ( 2 sites), 4 were injected with $5 \times 10^{3}$ SP cells in the left flank (4 sites) and the equivalent amount of NSP cells in the right flank (4 sites), 5 were injected with $1 \times 10^{4}$ or $1 \times 10^{5} \mathrm{SP}$ cells in the left flank and the equivalent amount of NSP cells in the right flank (10 sites), 2 were injected with $1 \times 10^{6}$ or $1 \times 10^{7}$ NSP cells in each flank (4 sites). Tumor formation in mice was monitored 6-8 weeks following implantation. Animals were sacrificed 3-6 weeks until the volume of xenograft tumors between 100 and $500 \mathrm{~mm}^{3}$. Tumor volume was calculated according to the following formula: Tumor volume $=(\mathrm{D} \times \mathrm{d} 2) / 2$, in which $\mathrm{D}$ indicates the long diameter of tumor and $\mathrm{d}$ represents the short diameter. The highest tumor volume was $526 \mathrm{~mm}^{3}$. All protocols were approved by the Ethics Committee and Animal Management Committee of the Tumor Hospital Affiliated to Guangxi Medical University (Nanning, China).

Immunohistochemical analysis. To determine whether there were differences in the expression of ABCG2 between SP and NSP xenograft tumor tissues from the aforementioned transplanted nude mice, immunohistochemical analysis was performed. The SP and NSP xenograft tumor tissues were fixed with $4 \%$ paraformaldehyde for $30 \mathrm{~min}$ at room temperature and treated with $2 \% \mathrm{H}_{2} \mathrm{O}_{2}$ for $30 \mathrm{~min}$. Then, tissues were probed using anti-ABCG2 mouse monoclonal antibody (dilution, 1:400; cat. no. ALX-801-036-C125, Alexis Biochemical, Switzerland) overnight at $4^{\circ} \mathrm{C}$. Subsequently, cells were incubated with $50 \mu$ l biotin-conjugated secondary antibody for $10 \mathrm{~min}$ at $25^{\circ} \mathrm{C}$ and maintained with $50 \mu \mathrm{l} \mathrm{strep-}$ tavidin-peroxidase for $10 \mathrm{~min}$ at $25^{\circ} \mathrm{C}$ using Ultrasensitive streptavidin-peroxidase kit (cat. no. KIT-9701/9702/9703; Fuzhou Maixin Biotech. Co., Ltd., Fuzhou, China) for $1 \mathrm{~h}$ at room temperature. The negative control used PBS as a substitute of the primary antibody. Following the reaction with 3,3'-diaminobenizidine with DAB kit (Fuzhou Maixin Biotech. Co., Ltd.), the cells were smeared onto slides and examined by optical microscopy (IX83, Olympus; magnification, x400). 


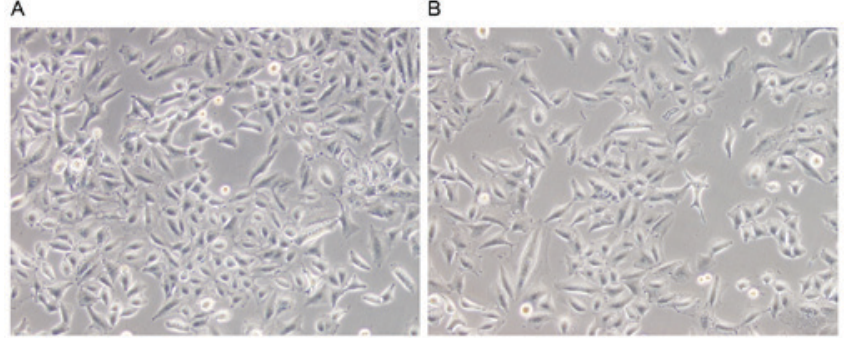

Figure 2. Side population (A) and non-side population cells (B) examined using optical microscopy (magnification, x100).
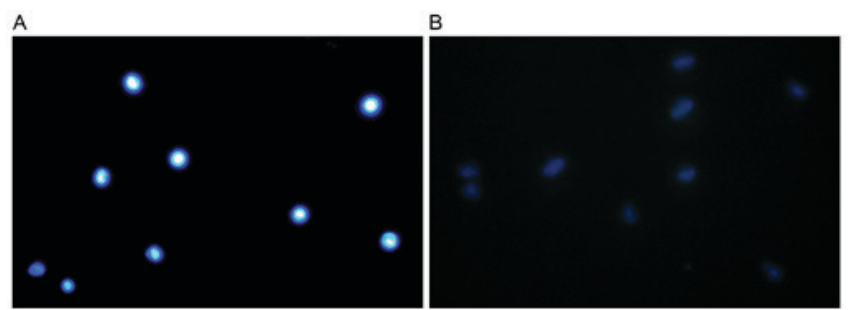

Figure 3. Side population and non-side population cells examined using fluorescence microscopy (magnification, x100). (A) NSP cells exhibited marked blue fluorescence signals. (B) SP cells demonstrated weak signals.

Finally, positive ABCG2 cells from $\geq 1,000$ counted cells demonstrated brown staining of the cell membrane or inside the cytoplasm and were counted.

Statistical analysis. Data were analyzed with SPSS 13.0 statistical software (SPSS, Inc., Chicago, IL, USA). The $\mathrm{IC}_{50}$ was calculated by Probit probability regression. Measurement data were expressed as the mean \pm standard deviation. An unpaired Student's t-test was used when the data of two groups were compared, while $\mathrm{d}^{2}$ test was used to compare xenograft tumorigenic activity of SP and NSP subpopulations in nude mice.

\section{Results}

FACS analysis of SP and non-SP cells. Hoechst $33342^{\text {low/neg }}$ cells (SP fraction) and Hoechst $33342^{\text {high }}$ cells (NSP fraction) were sorted from A549 cells by flow cytometry. The results demonstrated that the Hoechst $33342^{\text {low/neg }}$ fraction accounted for $1.09 \%$ of live cells and the percentage decreased to $0.2 \%$ subsequent to treatment with Verapamil. The sorted purity of SP cells was 99\% (Fig. 1A). One week following expanded culture in vitro, SP and NSP subpopulations in the logarithmic growth phase were re-stained with Hoechst 33342 dye and were sorted again. The results indicated that both Hoechst $33342^{\text {low/neg }}$ and Hoechst $33342^{\text {high }}$ cells were identified in the SP fraction, with $52.86 \%$ of living cells being Hoechst $33342^{\text {low/neg }}$ cells. However; the percentage decreased to $0.31 \%$ subsequent to treatment with Verapamil (Fig. 1B). However, only Hoechst $33342^{\text {high }}$ cells were isolated from the NSP fraction. Hoechst $33342^{\text {low/neg }}$ cells were identified at a low rate of $0.13 \%$ in living cells, which decreased to $0.06 \%$ following treatment with Verapamil (Fig. 1C).

In addition, fluorescence analysis of SP and NSP cells was performed. No morphological difference between SP and
Table I. Clone formation of SP and NSP cells.

\begin{tabular}{lccc}
\hline & \multicolumn{3}{c}{ Seeded cell number } \\
\cline { 2 - 4 } Cell fraction & 50 & 100 & 200 \\
\hline SP & $6.33 \pm 1.5$ & $13.33 \pm 1.53$ & $23.00 \pm 2$ \\
NSP & $3.33 \pm 0.58$ & $9.33 \pm 0.58$ & $17.00 \pm 2$ \\
t-test & 3.182 & 4.243 & 3.674 \\
P-value & 0.033 & 0.013 & 0.021 \\
\hline
\end{tabular}

SP, side population; NSP, non-side population.

NSP cells were observed using optical microscopy (Fig. 2), yet the NSP cells showed marked blue fluorescence signals (Fig. 3A) while SP cells showed weak signals (Fig. 3B) using fluorescence microscopy.

Plate cloning analysis. Plate cloning was performed to analyze the tumorigenicity of SP and NSP cells in vitro. The results demonstrated that more colonies were formed by the SP subpopulation compared with the NSP subpopulation. Additionally, the difference between the populations was statistically significant $(\mathrm{P}<0.001$; Table I).

Invasion analysis of SP and NSP cells in vitro. A Matrigel ${ }^{\circledR}$ Transwell assay was used to determine the invasive cell numbers for detecting the invasive ability of SP and NSP cells. A total of $24 \mathrm{~h}$ following incubation, the number of invaded SP and NSP cells was $60.00 \pm 3.00$ and $34.67 \pm 2.52$, respectively. The difference between them was statistically significant $(\mathrm{P}<0.01)$.

Chemoresistance analysis of SP and NSP cells. The SP and NSP cells were treated with different concentrations of 5 chemotherapeutic drugs, consisting of DDP, 5-FU, VP-16, NVB and GEM. The $\mathrm{IC}_{50}$ of DDP in SP and NSP cells was not statistically different $(\mathrm{P}>0.05)$, whereas the $\mathrm{IC}_{50}$ of $5-\mathrm{Fu}$, VP-16, NVB and GEM in SP cells was significantly increased compared with that of NSP cells $(\mathrm{P}<0.01$; Table II). In addition, the intracellular drug concentrations were examined. The results demonstrated that the intracellular DDP concentrations of SP and NSP cells were not statistically different $(\mathrm{P}>0.05)$, whereas the intracellular 5-FU, VP-16, NVB and GEM concentrations of SP cells were decreased compared with those of NSP cells, which was statistically significant $(\mathrm{P}<0.01$; Table III). Overall, SP cells exhibit increased resistance against chemotherapeutic drugs, including 5-FU, VP-16, NVB and GEM.

Xenograft tumor formation in BALB/c nude mice. A total of 3-5 weeks subsequent to injection of $1 \times 10^{5}$ SP cells, visible tumors were observed at all 5 injection sites of the nude mice, yet only 3 out of 5 injections resulted in detectable tumors at 7-8 weeks when $1 \times 10^{4} \mathrm{SP}$ cells were injected. Xenograft tumors were observed 4 weeks following injection at 2 injection sites of $1 \times 10^{7} \mathrm{NSP}$ cells, whereas no tumors were formed when low concentrations of NSP cells were injected (Table IV). The tumorigenic potential of SP cells in vivo was more marked 
Table II. Half maximal inhibitory concentration of chemotherapeutic drugs in SP and NSP cells.

\begin{tabular}{lccccc}
\hline & \multicolumn{3}{c}{ Drug, $\mu \mathrm{g} / \mathrm{ml}$} & NVB & GEM \\
\cline { 2 - 6 } Cell & DDP & $5-\mathrm{Fu}$ & VP-16 & $92.09 \pm 2.61$ & $102.92 \pm 4.21$ \\
SP & $138.55 \pm 9.53$ & $197.50 \pm 15.17$ & $170.49 \pm 3.02$ & $69.40 \pm 1.89$ & $75.30 \pm 2.80$ \\
NSP & $123.17 \pm 14.21$ & $127.92 \pm 7.11$ & $128.31 \pm 9.34$ & 12.209 & 9.461 \\
t-test & 1.809 & 7.194 & 7.440 & $<0.001$ & 0.001 \\
P-value & 0.195 & 0.002 & 0.002 & $<$ \\
\hline
\end{tabular}

SP, side population; NSP, non-side population; DDP, cisplatin; 5-Fu, 5-fluorouracil; VP-16, etoposide; NVB, vinorelbine; GEM, gemcitabine.

Table III. Intracellular drug concentrations of SP and NSP cells.

\begin{tabular}{lccccc}
\hline & \multicolumn{5}{c}{ Drug, $\mu \mathrm{g} / \mathrm{ml}$} \\
\cline { 2 - 6 } Cell & DDP & 5 -Fu & VP-16 & NVB & GEM \\
\hline SP & $0.090 \pm 0.007$ & $0.054 \pm 0.005$ & $0.491 \pm 0.008$ & $0.986 \pm 0.056$ & $0.179 \pm 0.009$ \\
NSP & $0.095 \pm 0.005$ & $0.098 \pm 0.005$ & $0.787 \pm 0.016$ & $2.804 \pm 0.072$ & $0.371 \pm 0.130$ \\
t-test & -0.957 & 11.161 & -27.904 & -35.224 & 27.681 \\
P-value & 0.393 & $<0.001$ & $<0.001$ & $<0.001$ & $<0.001$ \\
\hline
\end{tabular}

SP, side population; NSP, non-side population; DDP, cisplatin; 5-Fu, 5-fluorouracil; VP-16, etoposide; NVB, vinorelbine; GEM, gemcitabine.

Table IV. Number of xenograft tumor in nude mice following SP or NSP transplant.

\begin{tabular}{lccccc}
\hline & \multicolumn{2}{c}{ SP cells } & & \multicolumn{2}{c}{ NSP cells } \\
\cline { 2 - 3 } \cline { 5 - 6 } $\begin{array}{l}\text { Cell } \\
\text { number }\end{array}$ & $\begin{array}{c}\text { Injected } \\
\text { mice }\end{array}$ & Xenograft & $\begin{array}{c}\text { Injected } \\
\text { mice }\end{array}$ & Xenograft \\
\hline $1 \times 10^{7}$ & - & - & & 2 \\
$1 \times 10^{6}$ & - & - & & 2 & 0 \\
$1 \times 10^{5}$ & 5 & 5 & & 5 & 0 \\
$1 \times 10^{4}$ & 5 & 3 & & 5 & 0 \\
$5 \times 10^{3}$ & 4 & 0 & & 4 & 0 \\
$1 \times 10^{3}$ & 2 & 0 & & - \\
\hline
\end{tabular}

-, no data. SP, side population; NSP, non-side population.

compared with that of NSP cells. The tumorigenic ability of SP cells was significantly increased compared with that of NSP cells when $1 \times 10^{4}$ or $1 \times 10^{5}$ cells were transplanted into nude mice $\left(\chi^{2}=4.286, \mathrm{P}=0.038 ; \chi^{2}=10.000, \mathrm{P}=0.002\right)$.

Immunohistochemical analysis. ABCG2 expression in xenograft tumor tissues was analyzed by immunohistochemical analysis. The results demonstrated ABCG2 was expressed in all xenograft tumors. Additionally, the number of ABCG2 positive cells in the SP xenograft tumor was significantly increased compared with that in NSP xenograft tumors (Fig. 4).

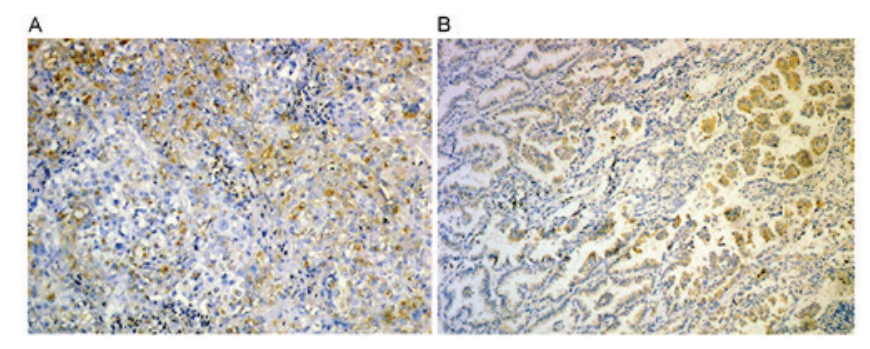

Figure 4. ABCG2 expression in xenograft tumor tissues examined by immunohistochemistry (magnification, $\mathrm{x} 400$ ). (A) Side population xenograft. (B) Non-side population xenograft.

\section{Discussion}

Extensive studies of CSCs have been conducted, yet for the majority of tumors, isolation and characterization of specific tumor stem cells remain a challenge. In the present study, cells with weak Hoechst 33342 staining were successfully sorted as SP cells from the human lung adenocarcinoma A549 cell line by flow cytometry sorting. The results demonstrated that SP cells accounted for $1.09 \%$ of live A549 cells. SP cells were able to be asymmetrically divided into SP and non-SP cells, while NSP cells were not. In addition, SP cells formed more colonies, exhibited improved invasive ability and chemoresistance compared with NSP cells in vitro. The results of the xenograft model in BALB/c nude mice also indicated that the SP cells exhibited increased tumorigenic potential in vivo compared with NSP cells, which was consistent with the results of the plate cloning assay 
in vitro. ABCG2 was expressed in all xenograft tumors, and the number of ABCG2-positive cells in SP xenograft tumors was significantly increased compared with that in NSP xenograft tumors. All these data suggest that SP cells exhibit CSC-associated properties, and may contribute to the development of lung cancer.

Self-renewal and multi-differentiation are considered to be important characteristics of stem cells (19). Kondo et al (20) proposed that a small subpopulation of stem cells maintained the malignant properties of cancer in a number of cancer tissues. According to their study, this subpopulation of stem cell was enriched in SP cells, and these SP cells were hypothesized to be able to differentiate into daughter SP cells and NSP cells via asymmetric division, which was also observed by Wang et al (21). In the present study, although there were no observed morphological differences between SP and NSP cells in the A549 cell line, the former subpopulation generated SP and NSP cells subsequent to culturing in vitro, while the latter only produced NSP cells (Fig. 1). It may therefore be hypothesized that SP cells, not NSP cells, exhibit multi-potent characteristics. In addition, plate cloning and xenograft tumor formation in $\mathrm{BALB} / \mathrm{c}$ nude mice was performed to validate the tumorigenic ability of SP cells in vitro and in vivo; the abilities of the SP cells were evident compared with those of NSP cells. These results are in accordance with previous data that SP cells exhibit highly tumorigenic capabilities, similar to CSCs, and that the transplantation of SP cells may lead to tumor formation $(22,23)$. Overall, these data of the present study may explain the multi-differential potential of SP cells.

According to the stem cell theory, the invasive properties of CSCs may result in tumor metastasis (24). Hermann et al (25) demonstrated that distinct populations of CSCs determined the metastatic activity of tumor in human pancreatic cancer. A study by Karnoub et al (26) also verified that mesenchymal stem cells may secrete chemokine (C-C motif) ligand 5, which was a critical factor for enhancing the invasion and metastasis of breast carcinoma via paracrine signaling on the cancer cells. The invasion ability of SP and NSP cells in the A549 cell line was also investigated in the present study, and the results indicated that SP cells possessed an improved invasive potential compared with the NSP cells, suggesting that the invasive ability of SP cells may maintain its malignant properties and contribute to the metastasis of lung cancer.

To additionally verify the presence of SP cells in the xenograft tumor tissue, ABCG2 expression in xenograft tumor tissues was detected. ABCG2 was previously considered as an effective marker for defining the phenotype of SP cells $(27,28)$. In addition, Yang et al (29) confirmed that elevated expression of ABCG2 in lung cancer SP cells is involved in multi-drug resistance. Hirschmann-Jax et al (30) also demonstrated that SP cells exhibited a high drug efflux capacity in neuroblastoma cells, indicating a higher sensitivity to chemotherapeutic agents of NSP cells compared with SP cells. The present study demonstrated that the susceptibility of SP cells to 5-FU, VP-16, NVB, and GEM, and the SP cell intracellular concentration of these drugs were all significantly lower compared with that of NSP cells. Therefore, elevated ABCG2 expression may induce the efflux of these drugs from lung cancer cells and increase chemoresistance: When the efflux capacity increased, chemotherapeutic resistance within the cells occurred. Several studies investigating antagonists of ABCG2-mediated resistance and transport have confirmed that ABCG2 is a target for cancer treatment $(31,32)$. Therefore, detecting ABCG2 expression may assist in predicting the chemotherapeutic outcome of patients, and serve as a useful target for curing lung cancer. However; it should be noted that no difference in DDP susceptibility and intracellular drug concentration of SP and NSP cells was observed. The present study hypothesizes that wild-type ABCG2 lacks the binding site for DDP, and is not able to expel DDP out of cells easily. Future experimental validations are required to verify this observation.

In conclusion, SP cells isolated from the human lung adenocarcinoma A549 cell line demonstrated higher tumorigenicity, increased invasive ability and exhibited improved chemoresistance compared with NSP cells. These SP cells may include stem-like tumor cells. In addition, detecting ABCG2 expression may assist in predicting the chemotherapeutic outcome of patients, and serve as a target for treating lung cancer. Future studies investigating these sorted SP cells may provide novel insights into the clinical treatment of this disease.

\section{Acknowledgements}

The authors would like to thank Dr Yangqing Lu (The Animal Science and Technology College Affiliated to Guangxi University, Nanning, China) for his technical assistance. The present study was supported by Guangxi Natural Science Research Fund (grant no. 0728084).

\section{References}

1. Peters S, Adjei AA, Gridelli C, Reck M, Kerr K and Felip E; ESMO Guidelines Working Group: Metastatic non-small-cell lung cancer (NSCLC): ESMO clinical practice guidelines for diagnosis, treatment and follow-up. Ann Oncol 23: vii56-vii64, 2012.

2. Jemal A, Bray F, Center MM, Ferlay J, Ward E and Forman D: Global cancer statistics. CA Cancer J Clin 61: 69-90, 2011.

3. Pardal R, Clarke MF and Morrison SJ: Applying the principles of stem-cell biology to cancer. Nat Rev Cancer 3: 895-902, 2003.

4. Visvader JE and Lindeman GJ: Cancer stem cells in solid tumours: Accumulating evidence and unresolved questions. Nat Rev Cancer 8: 755-768, 2008.

5. Reya T, Morrison SJ, Clarke MF and Weissman IL: Stem cells, cancer, and cancer stem cells. Nature 414: 105-111, 2001.

6. Al-Hajj M, Wicha MS, Benito-Hernandez A, Morrison SJ and Clarke MF: Prospective identification of tumorigenic breast cancer cells. Proc Natl Acad Sci USA 100: 3983-3988, 2003.

7. Ponti D, Costa A,Zaffaroni N,Pratesi G,Petrangolini G, CoradiniD, Pilotti S, Pierotti MA and Daidone MG: Isolation and in vitro propagation of tumorigenic breast cancer cells with stem/progenitor cell properties. Cancer Res 65: 5506-5511, 2005.

8. Eramo A, Lotti F, Sette G, Pilozzi E, Biffoni M, Di Virgilio A, Conticello C, Ruco L, Peschle C and De Maria R: Identification and expansion of the tumorigenic lung cancer stem cell population. Cell Death Differ 15: 504-514, 2008.

9. Goodell MA, Brose K, Paradis G, Conner AS and Mulligan RC: Isolation and functional properties of murine hematopoietic stem cells that are replicating in vivo. J Exp Med 183: 1797-1806, 1996.

10. Ho MM, Ng AV, Lam S and Hung JY: Side population in human lung cancer cell lines and tumors is enriched with stem-like cancer cells. Cancer Res 67: 4827-4833, 2007.

11. Hadnagy A, Gaboury L, Beaulieu R and Balicki D: SP analysis may be used to identify cancer stem cell populations. Exp Cell Res 312: 3701-3710, 2006.

12. Qi W, Zhao C, Zhao L, Liu N, Li X, Yu W and Wei L: Sorting and identification of side population cells in the human cervical cancer cell line HeLa. Cancer Cell Int 14: 3, 2014. 
13. Xie T, Li L, Li DR, Mao NQ, Liu DS, Zuo CT, Zhang W and Huang DM: Isolation and identification of side population cells in human lung adenocarcinoma cell line A549. Zhonghua Zhong Liu Za Zhi 33: 84-90, 2011 (In Chinese).

14. Haraguchi N, Utsunomiya $T$, Inoue $H$, Tanaka F, Mimori $K$, Barnard GF and Mori M: Characterization of a side population of cancer cells from human gastrointestinal system. Stem Cells 24: 506-513, 2006.

15. Szotek PP, Pieretti-Vanmarcke R, Masiakos PT, Dinulescu DM, Connolly D, Foster R, Dombkowski D, Preffer F, Maclaughlin DT and Donahoe PK: Ovarian cancer side population defines cells with stem cell-like characteristics and mullerian inhibiting substance responsiveness. Proc Natl Acad Sci USA 103: 11154-11159, 2006.

16. Murase M, Kano M, Tsukahara T, Takahashi A, Torigoe T, Kawaguchi S, Kimura S, Wada T, Uchihashi Y, Kondo T, et al: Side population cells have the characteristics of cancer stem-like cells/cancer-initiating cells in bone sarcomas. Br J Cancer 101: 1425-1432, 2009.

17. Zhou S, Schuetz JD, Bunting KD, Colapietro AM, Sampath J, Morris JJ, Lagutina I, Grosveld GC, Osawa M, Nakauchi H and Sorrentino BP: The ABC transporter Bcrp1/ABCG2 is expressed in a wide variety of stem cells and is a molecular determinant of the side-population phenotype. Nat Med 7: 1028-1034, 2001

18. Hu F, Deng C and Zhang X: Development of high performance liquid chromatography with immobilized enzyme onto magnetic nanospheres for screening enzyme inhibitor. J Chromatogr B Analyt Technol Biomed Life Sci 871: 67-71, 2008.

19. Shi MF, Jiao J, Lu WG, Ye F, Ma D, Dong QG and Xie X Identification of cancer stem cell-like cells from human epithelial ovarian carcinoma cell line. Cell Mol Life Sci 67: 3915-3925, 2010.

20. Kondo T, Setoguchi T and Taga T: Persistence of a small subpopulation of cancer stem-like cells in the C6 glioma cell line. Proc Natl Acad Sci USA 101: 781-786, 2004.

21. Wang YH, Li F, Luo B, Wang XH, Sun HC, Liu S, Cui YQ and $\mathrm{Xu}$ XX: A side population of cells from a human pancreatic carcinoma cell line harbors cancer stem cell characteristics. Neoplasma 56: 371-378, 2009.

22. Chiba T, Kita K, Zheng YW, Yokosuka O, Saisho H, Iwama A, Nakauchi $\mathrm{H}$ and Taniguchi $\mathrm{H}$ : Side population purified from hepatocellular carcinoma cells harbors cancer stem cell-like properties. Hepatology 44: 240-251, 2006.
23. Patrawala L, Calhoun T, Schneider-Broussard R, Zhou J, Claypool K and Tang DG: Side population is enriched in tumorigenic, stem-like cancer cells, whereas ABCG2+ and ABCG2- cancer cells are similarly tumorigenic. Cancer Res 65: 6207-6219, 2005

24. Croker AK and Allan AL: Cancer stem cells: Implications for the progression and treatment of metastatic disease. J Cell Mol Med 12: 374-390, 2008

25. Hermann PC, Huber SL, Herrler T, Aicher A, Ellwart JW, Guba M, Bruns CJ and Heeschen C: Distinct populations of cancer stem cells determine tumor growth and metastatic activity in human pancreatic cancer. Cell Stem Cell 1: 313-323, 2007.

26. Karnoub AE, Dash AB, Vo AP, Sullivan A, Brooks MW, Bell GW, Richardson AL, Polyak K, Tubo R and Weinberg RA: Mesenchymal stem cells within tumour stroma promote breast cancer metastasis. Nature 449: 557-563, 2007.

27. Shimano K, Satake M, Okaya A, Kitanaka J, Kitanaka N, Takemura M, Sakagami M, Terada N and Tsujimura T: Hepatic oval cells have the side population phenotype defined by expression of ATP-binding cassette transporter ABCG2/BCRP1. Am J Pathol 163: 3-9, 2003.

28. Britton KM, Eyre R, Harvey IJ, Stemke-Hale K, Browell D, Lennard TW and Meeson AP: Breast cancer, side population cells and ABCG2 expression. Cancer Lett 323: 97-105, 2012.

29. Yang B, Ma YF and Liu Y: Elevated expression of Nrf-2 and ABCG2 involved in multi-drug resistance of lung cancer SP cells. Drug Res (Stuttg) 65: 526-531, 2015.

30. Hirschmann-Jax C, Foster AE, Wulf GG, Nuchtern JG, Jax TW, Gobel U, Goodell MA and Brenner MK: A distinct 'side population' of cells with high drug efflux capacity in human tumor cells. Proc Natl Acad Sci USA 101: 14228-14233, 2004.

31. Ding R, Shi J and Scotto KW: Modulation of ABCG2 mediated multidrug resistance by xanthine derivatives. Cancer Res 71: 1746-1746, 2011

32. Takara K, Yamamoto K, Matsubara M, Minegaki T, Takahashi M, Yokoyama T and Okumura K: Effects of $\alpha$-adrenoceptor antagonists on ABCG2/BCRP-mediated resistance and transport. PLoS One 7: e30697, 2012.

This work is licensed under a Creative Commons Attribution-NonCommercial-NoDerivatives 4.0 International (CC BY-NC-ND 4.0) License. 